\title{
EFL Learners' Self-efficacy, Metacognitive Awareness, and Use of Language Learning Strategies: How Are They Associated?
}

\author{
Mania Nosratinia \\ Islamic Azad University at Central Tehran, Iran \\ Maryam Saveiy \\ Islamic Azad University at Central Tehran, Iran
}

Alireza Zaker

Islamic Azad University, Science and Research Branch, Tehran, Iran

\begin{abstract}
This study aimed at exploring the relationship among EFL learners' self-efficacy, metacognitive awareness, and language learning strategy use. To this aim, 150 EFL learners majoring in English Translation and English Literature at Karaj and Sari Islamic Azad Universities were randomly selected and were asked to fill in the three questionnaires on General Self-Efficacy Scale (GSES) by Schwarzer, \& Jerusalem (1996), Metacognitive Awareness Inventory (MAI) by Schraw \& Dennison (1994) and Strategy Inventory for Language Learning (SILL) by Oxford (1990). After discarding incomplete answer sheets, 143 acceptable cases were used in statistical analyses. Preliminary analyses were performed to ensure no violation of the assumptions of normality, linearity and homoscedasticity. The relationship among GSES, MAI, and SILL was investigated using Pearson's product-moment correlation coefficient. Statistical analysis indicated that significant relationships exist between EFL learners' self-efficacy and metacognitive awareness, self-efficacy and use of language learning strategies, and metacognitive awareness and use of language learning strategies. Moreover, regression analysis revealed that significant difference exists between EFL learners' self-efficacy and metacognitive awareness in predicting use of language learning strategies in a way that metacognitive awareness entered the model as the best predictor of language learning strategies. It can be concluded that, the obtained results may help EFL teachers and educators to bear in mind the benefits of developing their learners' self-efficacy and metacognitive awareness when dealing with promoting language learning strategies in learners.
\end{abstract}

Index Terms - individual differences, language learning strategies, metacognitive awareness, self-efficacy

\section{INTRODUCTION}

Most of the theories of learning are all attempts to describe universal human traits which are influential in the process of learning (Brown, 2007). These theories intend to account for the way human beings recognize, filter, store, and remember information. However, it seems that processes like these do not sufficiently explain the differences among people regarding how they learn and the dissimilarities within every person (Brown, 2007) which are very important factors in the process of learning.

During the past decades, there has been a gradual but significant shift among language educators from "teachercentered to more learner-centered approaches" (Riazi, 2007, p. 433) in the field of English as a Foreign Language (EFL). This shift gave rise to many studies on the effect of various factors such as socio-cultural, psychological, cognitive, and affective variables on learning, particularly on second language learning (Brown, 2000; Nunan, 1988). Today, it is almost known that each learner has his/her especial way of learning that may have a fundamental role in his/her success or failure (Fewell, 2010; Zare \& Noordin, 2011). Most of the researchers have gradually moved from focusing on teaching paradigms toward exploring individual characteristics (Carson \& Longhini, 2002; Oxford \& Anderson, 1995). Therefore, the learners and their individual variables have been the subject of many studies.

Educators and researchers in the field of applied linguistics believe that these variables are the origin of dissimilarities among L2 learners in language learning (Dörnyei, 2009). The growing interest in the function of these variables has been the driving force for many studies which inspect individual learning styles and language learning strategies (LLS) and the way they are associated to success in L2 learning (Green \& Oxford, 1995; Griffiths \& Parr, 2000; Hsiao \& Oxford, 2002; Wharton, 2000). In this regard, Chamot (2001) states that:

Applied research on language learning strategies had two major goals: (1) Identify and compare the learning strategies used by more and less successful language learners, and (2) Provide instruction to less successful learners that helps them become more successful in their language study. (p. 25) 
Language learning strategies are known to be the certain acts and behaviors that learners intentionally or unintentionally use to facilitate their L2 skills' development. These techniques make the internalization, storage, retrieval, and use of the new language much easier. They are regarded as specialized tools for a self-directed involvement which is necessary for improving language skills (Oxford, 1990).

Generally, studies conducted on use of language learning strategies (Dreyer \& Oxford, 1996; Grenfell \& Harris, 1999; Wharton, 2000) point to the fact that language learners, consciously or unconsciously, employ a range of language learning strategies which help them increase their knowledge and comprehension of a second/target language. They are the conscious thoughts and behaviors which are used by the learners to smooth language learning tasks and to make the language learning process more personal (Cohen, Ledford, \& Spreitzer, 1996). It can be argued that successful language learners utilize more effective and diverse language learning strategies than less successful learners (Oxford, 2003). Due to the fact that language learning strategies have a great role in facilitating the acquisition, storage, retrieval/use of information, gaining higher degrees of autonomy, and self-confidence improvement, it is important to help learners achieve greater control over their own learning through using strategies.

Another important cognitive factor which helps learners to become more effective and, importantly, more autonomous is developing metacognitive awareness (Winne \& Hadwin, 1998). Metacognitive awareness is described as knowing how you think. When it comes to an ELT classroom, it is equal to being aware of the way you acquire the knowledge of language. If learners are conscious of how they learn, then they can identify the most effective ways of doing so.Metacognitive knowledge is regarded as the high order executive skills that employ the knowledge of cognitive processes and found an attempt to control and adjust ones' own learning process through planning, monitoring, and evaluating (Livingstone, 2003). Students who know better regarding the way of studying and learning (i.e., those who possess a higher degree of metacognitive knowledge) learn better (Winne \& Hadwin, 1998). Moreover, Chamot (2004) stated that "Strategic language learners possess metacognitive knowledge about their own thinking and learning approaches, a good understanding of what a task entails, and the ability to orchestrate the strategies that best meet both the task demands and their own strengths" (p. 14). In order for learners to use metacognitive strategies to enhance their learning, they need to be aware of their own learning tendencies and control their learning (Conner, 2006; White \& Frederiksen, 1998; Winne, 1995).

One of the most important and influential factors of metacognitive awareness which helps learners gain enough confidence in order to be autonomous and successful is self-efficacy (Bandura, 1989; Bouffard-Bouchard, Parent, \& Larivèe, 1991; Coutinho, 2007). The concept of self-efficacy is rooted in the socio-cognitive theory (Jalaluddin, 2013). It was proposed for the first time by Bandura (as cited in Su and Due, 2012). Bandura (1986) states that self-efficacy is learners' judgment of their capacities to identify and carry out something to master some specific functions. According to Çubukçu (2008) "Self-efficacy deals with cognitively perceived capability of the self" (p. 150). Whether or not a person can do what leads to the desired success is the focus of efficacy. Put another way, self-efficacy is linked to learners' beliefs about their abilities of completing and undertaking a task. It can be regarded as the question students ask themselves, asking "if I can do it?". It is widely accepted that learners who possess a stronger sense of selfconfidence and/or self-efficacy can organize their own learning process better and are more prepared for expending their efforts, whereas learners with lower degree of self-efficacy are less motivated and usually do not exhibit enough interest in learning which causes encountering academic failure (Elias, Mahyuddin, Noordin, Abdullah, \& Roslan, 2009).

Many studies have indicated that self-efficacy has significant and positive correlation with learner's academic performance (e.g. Chou, 2007; Ho, 2005; Lin, 2002; Mills, Pajares, \& Herron, 2007). Moreover, some other groups of studies have focused on the relationship between self-efficacy and use of learning strategies. For instance, Zimmerman (1990) indicated that individual's self-efficacy has a significant relationship with the effective use of learning strategies. In this respect, Chamot, Barnhardt, El-Dinary and Robbins (as cited in Ho, 2005) argued that the difference between more and less effective learners lies in the quantity and range of employed strategies, in the way the strategies are applied to the task, and in the appropriateness of tasks.

Considering the important role of language learning strategies and metacognitive awareness as the bridge between areas such as thinking and memory, learning and motivation, and learning and cognitive development (Metcalfe \& Shimamura, as cited in Heidari \& Bahrami, 2012), on the one hand, and the existence of a positive relationship between students' learning strategies and self-efficacy (Magogwe, Mokuedi, \& Oliver, 2007; Siew \& Wong, 2005) on the other hand, this study focused on the relationship among these three important variables: language learning strategies, metacognitive awareness, and self-efficacy.

Although many studies have been conducted on language learning strategies, metacognitive awareness, and selfefficacy two by two in the context of Iran, (Abedini, Rahimi, \& Zaree, 2011; Bonyadi, Rimani Nikou, \& Shahbaz, 2012; Heidari, Izadi, \& Vahed Ahmadian, 2012) it seems that no study has addressed the relationship among these three variables simultaneously. Since, Iranian learners are not high strategy users (Riazi \& Rahimi, 2005; Zare 2010) the findings of the present study would reveal if this lack of strategy use is associated with and/or affected by their selfefficacy and metacognitive awareness. Furthermore, the findings of the present study can contribute to the field of teaching English as a foreign language by providing more knowledge and information about characteristics of EFL 
learners in terms of their efficacy beliefs, metacognitive awareness, and their use of language learning strategies. In this regard, the following research questions were formulated:

$Q_{1}$ : Is there any significant relationship among EFL learners' self-efficacy, metacognitive awareness, and use of language learning strategies?

$Q_{2}$ : Is there any significant relationship between EFL learners' different types of metacognitive awareness and their self-efficacy?

$Q_{3}:$ Is there any significant relationship between EFL learners' use of language learning strategies and their selfefficacy?

$Q_{4}:$ Is there any significant relationship between EFL learners' use of language learning strategies and their different types of metacognitive awareness?

Provided that a significant correlation is obtained between the variables two by two, the following question was also raised:

$Q_{5}:$ Is there any significant difference between EFL learners' self-efficacy and metacognitive awareness in predicting their use of language learning strategies?

\section{METHOD}

\section{Participants}

The participants of this study were 143 sophomore, junior, and senior students (109 females and 34 males) with the age range of 18-25, studying English Translation and English Literature at Karaj and Sari Islamic Azad Universities. It should be mentioned that the preliminary number of participants was 150 (112 females, 38 males), but 7 of them were excluded from data analysis due to careless coding, incomplete answers, and subject mortality, bringing the final number to 143 participants.

\section{Instrumentation}

\section{Self-Efficacy Questionnaire}

To assess learners' level of self-efficacy, a questionnaire of General Self-Efficacy Scale (GSES) including 10 items designed by Schwarzer and Jerusalem (1996) was employed. It requires five minutes on average to answer the questions. Responses are made on a four-point Likert scale. Responses to all 10 items are summed up to yield the final score, with a range from 10 to 40 .

Regarding the reliability of this questionnaire, Cronbach's alphas ranged from 0.76 to 0.90 based on the results of studies which gathered from 23 nations. Moreover, related validity is documented in many descriptive studies where positive coefficients have been observed with favorable emotions, dispositional optimism, and work satisfaction. Negative coefficients have been found with depression, anxiety, stress, burnout, and health complaints (Schwarzer, Bäßler, Kwiatek, Schröder, \& Zhang, 1997; Schwarzer, Born, Iwawaki, Lee, Saito, \& Yue, 1997).

In the present study, the Persian version of the instrument, translated by Nezami (2000), was administered. The reliability of the Persian version had been measured in Iranian studies, and the obtained Cronbach's alphas ranged from 0.79 to 0.88 (Bastani, 2012; Dehdari, Heidarnia, Ramezankhani, Sadeghian, \& Ghofranipour, 2008). In the present study, its reliability was computed through K-R21 formula which turned out to be 0.78 .

\section{Metacognitive Awareness Questionnaire}

The Metacognitive Awareness Inventory (MAI), developed by Schraw and Dennison (1994) was utilized to assess metacognitive awareness of the participants. It includes 52 items which assesses various facets of metacognition. Items of MAI are under two categories: "Knowledge of Cognition" and "Regulation of Cognition". Seventeen items of the MAI measure knowledge of cognition, and the remaining thirty five items assess regulation of cognition. Table1 demonstrates the eight components of MAI and the related items.

TABLE 1:

COMPONENTS AND ITEMS OF MAI

\begin{tabular}{|l|l|l|}
\hline Components & Number of Items in Each Component & Total Number of Items \\
\hline Knowledge about Cognition & $5,10,12,16,17,20,32,46$ & 8 \\
\hline Declarative Knowledge & $3,14,27,33$ & 4 \\
\hline Procedural Knowledge & $15,18,26,29,35$ & 5 \\
\hline Conditional Knowledge & $4,6,8,22,23,42,45$ & 7 \\
\hline Regulation of Cognition & $9,13,30,31,37,39,41,43,47,48$ & 10 \\
\hline Planning & $25,40,44,51,52$ & 5 \\
\hline Information Management Strategies & $1,2,11,21,28,34,49$ & 7 \\
\hline Debugging Strategy & $7,18,24,36,38,49$ & 6 \\
\hline Comprehension Monitoring & \\
\hline Evaluation & & \\
\hline
\end{tabular}

The responses are based on true and false scale. The participants are supposed to answer the items in 30 minutes. Different studies have supported the satisfactory reliability and validity of the instrument. The internal consistency (reliability) for the knowledge of cognition scale has varied from the low 0.70 s to the high 0.80 s and for the regulation of cognition scale has varied from the low 0.80 s to the high 0.90 s. For the entire inventory, the internal reliability has 
been reported to be 0.90 (Schraw \& Dennison, 1994; Sperling, Staley, \& Du Bois, 2004; Zhang, 2010). The validity of the this instrument has been inspected and substantiated by Schraw and Dennison (1994) who performed a two-factor solution on the data. The result supported two factors accounting for $65 \%$ of the sample variance.

Since the questionnaire is designed for the native speakers, to avoid any misunderstanding in part of cultural differences and not having enough knowledge of some of the participants in vocabulary and grammar, the researchers used the Persian translated version of the questionnaire. Its reliability was ensured in different studies through Cronbach's alpha which ranged from 0.74 to 0.96 (Delavarpoor \& Motahedi, 2007; Marzoogh \& Safari, 2009; Shahniyeilagh, Boostani, Alipoor, \& Hajiyakhchali, 2012).

The reliability of MAI questionnaire, in this study, was estimated to be 0.95 using the K-R 21 formula, which demonstrated a fair degree of reliability. Table 2 shows the reliability of MAI and its components.

TABLE 2:

RELIABILITY INDEX OF MAI AND ITS COMPONENTS

\begin{tabular}{|l|l|l|}
\hline Reliability Statistics & K-R21 & N of Items \\
\hline & .95 & 52 \\
\hline MAI & .70 & 8 \\
\hline Declarative Knowledge & .68 & 4 \\
\hline Procedural Knowledge & .52 & 5 \\
\hline Conditional Knowledge & .66 & 7 \\
\hline Planning & .72 & 10 \\
\hline Information Management Strategies & .76 & 5 \\
\hline Debugging Strategy & .89 & 7 \\
\hline Comprehension Monitoring & .77 & 6 \\
\hline Evaluation & & \\
\hline
\end{tabular}

\section{Strategy Inventory for Language Learning (SILL)}

The Strategy Inventory for Language Learning (SILL), developed by Oxford (1990) was used in this study. The 50item version of SILL, used in this study, covers six categories of strategies for language learning: Items 1-9 concern the effectiveness of memory (memory strategies); items 10-23 concern the use of mental processes (cognitive strategies); items 24-29 are the compensation for missing knowledge (compensation strategies); items 30-38 deal with the organization and evaluation of learning (metacognitive strategies); items 39-44 concern emotion management (affective strategies); and items 45-50 deal with learning with others (social strategies). The participants responded on a fivepoint Likert scale ranging from 1 "Never or Almost Never" to 5 "Always or Almost Always". The recommended time was 30 minutes. The range of scores for SILL is between 50 and 250. The higher score means that the participant is an efficient strategy user, and the lower the score means that the participant is not an efficient strategy user.

According to Ehrman and Oxford (1995), SILL has mostly scored above 90 using Cronbach's alpha which indicates high internal reliability. Oxford (1996) reported Cronbach's alpha of 0.96 for SILL. SILL was translated to Persian, and its content validity was checked by Tahmasebi (1999). Tahmasebi (ibid) argues that the validation process of the translated version has happened through collaboration of some professors at Islamic Azad University while analyzing the data through related procedures. Moreover, Tahmasebi (1999) reported Cronbach's alpha of 0.77 for Persian version of SILL.

In this study, to avoid any misinterpretation, the researchers administered the translated version of the SILL questionnaire (Tahmasebi, 1999) which consists of 50 multiple-choice items. Each item has four options ranging from "Never" to "Always" with a range of scores between 1 and 5. Therefore, the ultimate score is estimated in the possible range of 50 to 250 , and the participants are supposed to answer the items in 30 minutes. The reliability of SILL questionnaire in this study was estimated to be 0.97 using the K-R 21 reliability indices, which demonstrated a fair degree of reliability. Table 3 shows the reliability of SILL and its components.

TABLE 3:

RELIABILITY INDEX OF SILL AND ITS COMPONENTS

\begin{tabular}{|l|l|l|}
\hline Reliability Statistics & K-R21 & N of Items \\
\hline SILL & $\mathbf{9 7}$ & $\mathbf{5 0}$ \\
\hline Memory & 82 & 9 \\
\hline Cognitive & 69 & 14 \\
\hline Compensation & 60 & 6 \\
\hline Metacognitive & 71 & 9 \\
\hline Affective & 77 & 6 \\
\hline Social & 69 & 6 \\
\hline
\end{tabular}

\section{Procedure}

In order to achieve the purpose of the study, the following procedure was carried out. All participants of the study were randomly selected from among both male and female sophomore, junior and senior students majoring in English Translation and English Literature at Karaj and Sari Islamic Azad Universities. 
Before administrating the questionnaires, the participants were fully briefed on the process of completing the questionnaires; this briefing was given in Persian through explaining and exemplifying the process of choosing answers. Then, a package of three distinct questionnaires was given in one session in order to collect the required data of this study. It should be mentioned that, the researchers intentionally randomized the order of questionnaires in each package to control for the impact of order upon the completion process and validity of the data.

The initial package included the English version of the questionnaires, but in the course of administration, it was found that many of the participants could not answer many of the items. To overcome this problem which was due to misunderstanding, not having enough knowledge of vocabulary and grammar, and cultural differences, the researchers administered the Persian version of the questionnaires, and the English questionnaires were excluded from the data. The participants were asked to complete the questionnaires approximately in 65 minutes. Moreover, the researchers randomly observed the process of filling out for some individuals to make sure they were capable to fully understand the questions and responses.

Out of 150 students who took part in the administration, seven of them were excluded from data analysis due to careless coding and incomplete answers, bringing the final number to 143 participants among which 109 (76\%) were females and $34(24 \%)$ males. The justification for the lower number of males in the context of this study is that female candidates usually outnumber males in selecting English as their major in university entrance exam.

\section{RESULTS}

In order to answer the research questions of the study, the descriptive statistics were obtained and the assumptions of linear correlation were checked, the results of which are presented hereunder.

\section{Testing the Basic Assumptions}

Since the present data were analyzed through Pearson's correlation and regression analyses, five assumptions of interval data, independence of subjects, normality, homoscedasticity and linearity should be met. The data should be measured on an interval scale. The subjects should be independent, that is to say their performance on the test is not affected by the performance of other students. The data should enjoy normal distribution, the relationships between the variables should be linear, and finally, the residuals should have homogeneous variances (homoscedasticity).

The present data were measured on an interval scale. The subjects performed independently on the questionnaires. The assumption of normality is met; the values of skewness and kurtosis are within the ranges of $+/-1.96$ as shown in Tables 4 and 5 .

TABLE 4:

DESCRIPTIVE STATISTICS OF SILL, MAI, AND GSES

\begin{tabular}{lllll}
\multicolumn{5}{c}{ DESCRIPTIVE STATISTICS OF SILL, MAI, AND GSES } \\
\hline & $\mathrm{N}$ & $\mathrm{Mean}$ & Variance & K-R21 \\
\hline SILL & 143 & 160.22 & 1037.358 & 0.97 \\
\hline MAI & 143 & 35.83 & 152.173 & 0.95 \\
\hline GSES & 143 & 30.72 & 29.780 & 0.78 \\
\hline
\end{tabular}

TABLE 5:

TESTING NORMALITY ASSUMPTIONS, SILL, MAI AND GSES

\begin{tabular}{llllll}
\hline & $\mathrm{N}$ & Skewness & & Kurtosis \\
\cline { 2 - 5 } & Statistic & Statistic & Std. Error & Statistic & Std. Error \\
\hline SILL & 143 & .036 & .203 & .092 & .403 \\
\hline MAI & 143 & -.473 & .203 & -.567 & .403 \\
\hline Memos & 143 & -.549 & .203 & -.045 & .403 \\
\hline Cognitive & 143 & .099 & .203 & -.454 & .403 \\
\hline Compensation & 143 & .225 & .203 & -.225 & .403 \\
\hline Metacognitive & 143 & -.258 & .203 & .047 & .403 \\
\hline Affective & 143 & -.287 & .203 & .683 & .403 \\
\hline Social & 143 & .559 & .203 & .136 & .403 \\
\hline Declarative Knowledge & 143 & -.332 & .203 & .427 & .403 \\
\hline Procedural Knowledge & 143 & -.609 & .203 & -.568 & .403 \\
\hline Conditional Knowledge & 143 & -.533 & .203 & -.660 & .403 \\
\hline Planning & 143 & -.446 & .203 & -.642 & .403 \\
\hline Information Management Strategies & 143 & -.377 & .203 & -.750 & .403 \\
\hline Debugging Strategies & 143 & -.452 & .203 & .076 & .403 \\
\hline Comprehension Monitoring & 143 & -.928 & .203 & .262 & .403 \\
\hline Evaluation & 143 & -.479 & .203 & .509 & .403 \\
\hline
\end{tabular}

The assumptions of linearity and homoscedasticity are discussed when reporting the results of the regression and correlations, although in this case the assumptions are violated; therefore, one can make inferences only for the immediate population from which the sample was selected (Little, 2004).

\section{Answering the Research Questions}

Following the descriptive statistics of the study, the first four research questions were answered through correlational analysis and the next fifth question through regression analysis of the data. 


\section{The First Research Question}

The Pearson's correlation was run to probe any significant relationships among EFL learners' self-efficacy, metacognitive awareness, and use of language learning strategies. Based on the results displayed in Table 6, it can be concluded that there were significant relationships between:

A: Language learning strategies and metacognitive awareness $[\mathrm{r}(143)=.87, p<.05$, it represented a large effect size].

B: Language learning strategies and general self-efficacy $[\mathrm{r}(143)=.80, p<.05$, it represented a large effect size $]$.

C: Metacognitive awareness and general self-efficacy $[\mathrm{r}(143)=.91, p<.05$, it represented a large effect size].

TABLE 6:

PEARSON CORRELATION; SILL, MAI, AND GSES

\begin{tabular}{|c|c|c|c|}
\hline \multirow{3}{*}{ SILL } & Pearson Correlation & $.871^{\text {w/ }}$ & $.803^{* *}$ \\
\hline & Sig. (2-tailed) & .000 & .000 \\
\hline & $\mathrm{N}$ & 143 & 143 \\
\hline \multirow{4}{*}{ MAI } & Pearson Correlation & & $.915^{* *}$ \\
\hline & Sig. (2-tailed) & & .000 \\
\hline & \multirow{2}{*}{$\mathrm{N}$} & & 143 \\
\hline & & & \\
\hline
\end{tabular}

As displayed in Figure 1, despite minor outliers, the relationships between the three variables were linear.

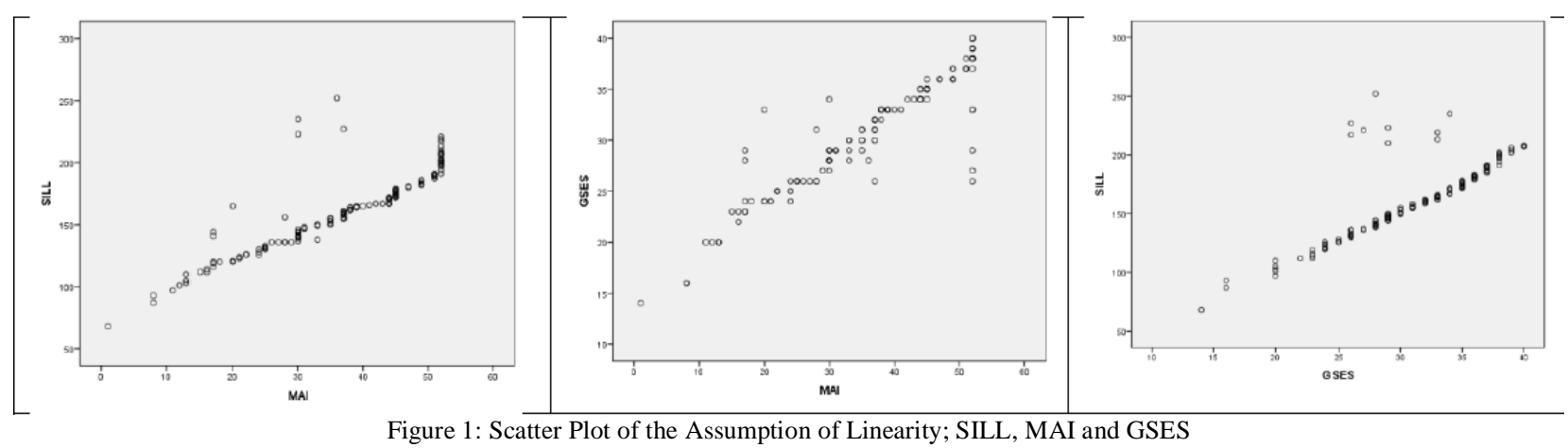

\section{The Second Research Question}

The Pearson correlation was run to probe any significant relationships between components of metacognitive awareness and general self-efficacy. Based on the results displayed in Table 7, it can be concluded that general selfefficacy scale shows significant relationships with:

A: Declarative knowledge [ $\mathrm{r}(143)=.87, p<.05$, it represented a large effect size].

B: Procedural knowledge $[\mathrm{r}(143)=.86, p<.05$, it represented a large effect size].

C: Conditional knowledge $[\mathrm{r}(143)=.87, p<.05$, it represented a large effect size].

D: Planning [r $(143)=.89, p<.05$, it represented a large effect size].

$\mathrm{E}$ : Information management $[\mathrm{r}(143)=.88, p<.05$, it represented a large effect size].

F: Debugging strategy $[\mathrm{r}(143)=.88, p<.05$, it represented a large effect size].

$\mathrm{G}$ : Compensation Monitoring $[\mathrm{r}(143)=.92, p<.05$, it represented a large effect size]. \&

$\mathrm{H}$ : Evaluation $[\mathrm{r}(143)=.89, p<.05$, it represented a large effect size]. 
TABLE 7:

PEARSON CORRELATION; GSES WITH COMPONENTS OF METACOGNITIVE AWARENESS INVENTORY

\begin{tabular}{|c|c|c|}
\hline & & GSES \\
\hline \multirow{3}{*}{$\begin{array}{l}\text { Declarative } \\
\text { Knowledge }\end{array}$} & Pearson Correlation & $.876^{* *}$ \\
\hline & Sig. (2-tailed) & .000 \\
\hline & $\mathrm{N}$ & 143 \\
\hline \multirow{3}{*}{$\begin{array}{l}\text { Procedural } \\
\text { Knowledge }\end{array}$} & Pearson Correlation & $.866^{* *}$ \\
\hline & Sig. (2-tailed) & .000 \\
\hline & $\mathrm{N}$ & 143 \\
\hline \multirow{3}{*}{$\begin{array}{l}\text { Conditional } \\
\text { Knowledge }\end{array}$} & Pearson Correlation & $.874^{* *}$ \\
\hline & Sig. (2-tailed) & .000 \\
\hline & $\mathrm{N}$ & 143 \\
\hline \multirow{3}{*}{ Planning } & Pearson Correlation & $.892^{* *}$ \\
\hline & Sig. (2-tailed) & .000 \\
\hline & $\mathrm{N}$ & 143 \\
\hline \multirow{3}{*}{ Information Management } & Pearson Correlation & $.888^{* *}$ \\
\hline & Sig. (2-tailed) & .000 \\
\hline & $\mathrm{N}$ & 143 \\
\hline \multirow{3}{*}{$\begin{array}{l}\text { Debugging } \\
\text { Strategy }\end{array}$} & Pearson Correlation & $.889^{* *}$ \\
\hline & Sig. (2-tailed) & .000 \\
\hline & $\mathrm{N}$ & 143 \\
\hline \multirow{3}{*}{$\begin{array}{l}\text { Compensation } \\
\text { Monitoring }\end{array}$} & Pearson Correlation & $.921^{* * 4}$ \\
\hline & Sig. (2-tailed) & .000 \\
\hline & $\overline{\mathrm{N}}$ & 143 \\
\hline \multirow{3}{*}{ Evaluation } & Pearson Correlation & $.893^{* *}$ \\
\hline & Sig. (2-tailed) & .000 \\
\hline & $\mathrm{N}$ & 143 \\
\hline
\end{tabular}

As displayed in Figure 2, despite minor outliers, the relationships between the variables were linear.

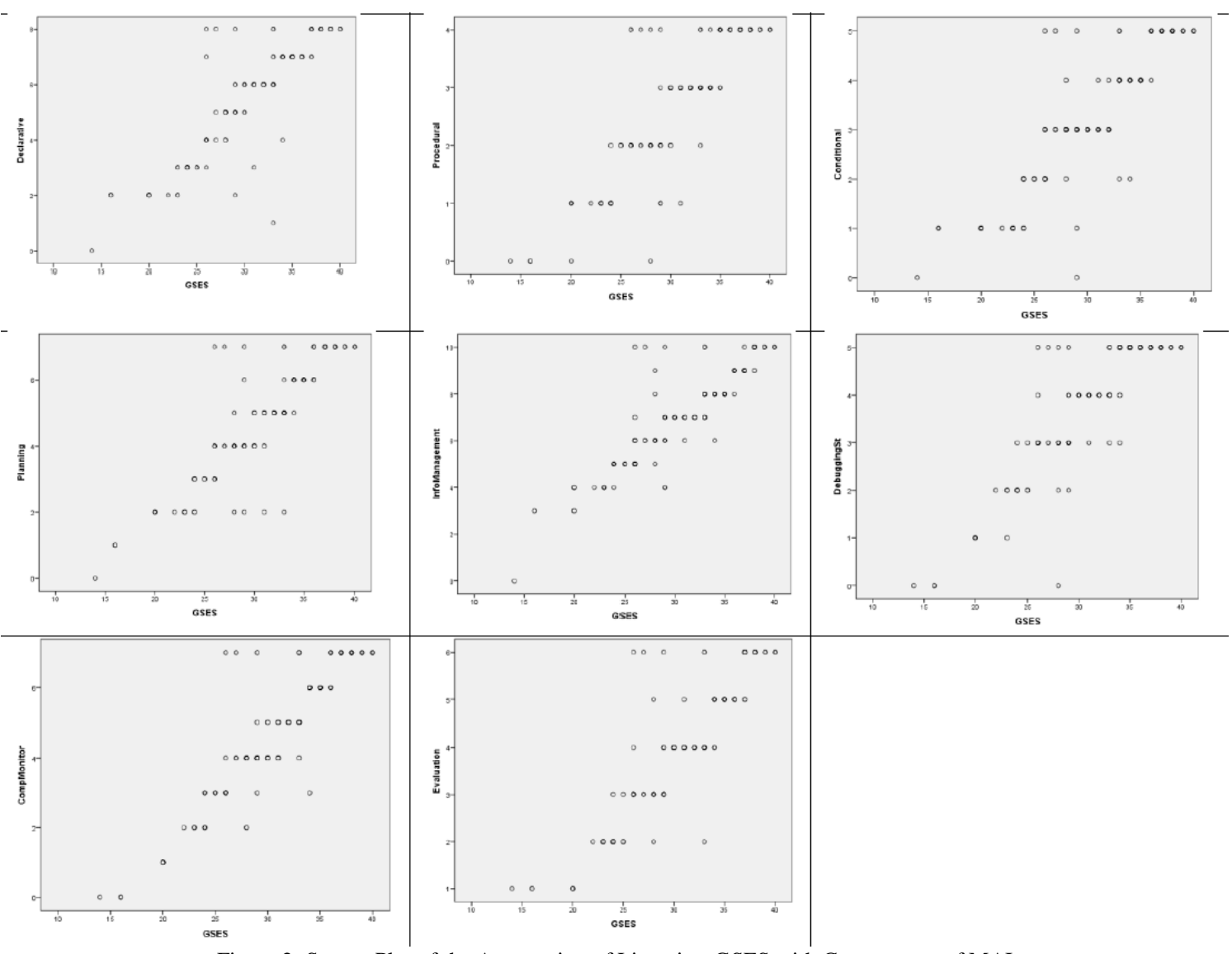

Figure 2: Scatter Plot of the Assumption of Linearity; GSES with Components of MAI

\section{The Third Research Question}

The Pearson correlation was run to probe any significant relationships between components of language learning strategies and general self-efficacy. Based on the results displayed in Table 8, it can be concluded that general selfefficacy scale shows significant relationships with: 
A: Memory Strategy $[\mathrm{r}(143)=.79, p<.05$, it represented a large effect size].

B: Cognitive Strategy [r $(143)=.77, p<.05$, it represented a large effect size].

C: Compensation Strategy $[\mathrm{r}(143)=.81, p<.05$, it represented a large effect size].

D: Metacognitive Strategy [r $(143)=.81, p<.05$, it represented a large effect size].

E: Affective Strategy $[\mathrm{r}(143)=.71, p<.05$, it represented a large effect size]. \&

F: Social Strategy $[\mathrm{r}(143)=.82, p<.05$, it represented a large effect size].

TABLE 8:

PEARSON CORRELATION; SELF-EFFICACY WITH COMPONENTS OF LANGUAGE LEARNING STRATEGIES

\begin{tabular}{|c|c|c|}
\hline & & GSES \\
\hline \multirow{3}{*}{ Memory Strategy } & Pearson Correlation & $.795^{* *}$ \\
\hline & Sig. (2-tailed) & .000 \\
\hline & $\mathrm{N}$ & 143 \\
\hline \multirow{3}{*}{ Cognitive Strategy } & Pearson Correlation & $.772^{* * *}$ \\
\hline & Sig. (2-tailed) & .000 \\
\hline & $\mathrm{N}$ & 143 \\
\hline \multirow{3}{*}{ Compensation Strategy } & Pearson Correlation & $.814^{* * *}$ \\
\hline & Sig. (2-tailed) & .000 \\
\hline & $\mathrm{N}$ & 143 \\
\hline \multirow{3}{*}{ Metacognitive Strategy } & Pearson Correlation & $.816^{* *}$ \\
\hline & Sig. (2-tailed) & .000 \\
\hline & $\mathrm{N}$ & 143 \\
\hline \multirow{3}{*}{ Affective strategy } & Pearson Correlation & $.718^{* *}$ \\
\hline & Sig. (2-tailed) & .000 \\
\hline & $\mathrm{N}$ & 143 \\
\hline \multirow{3}{*}{ Social Strategy } & Pearson Correlation & $.827^{* *}$ \\
\hline & Sig. (2-tailed) & .000 \\
\hline & $\mathrm{N}$ & 143 \\
\hline
\end{tabular}

As displayed in Figure 3, despite minor outliers, the relationships between the variables were linear.
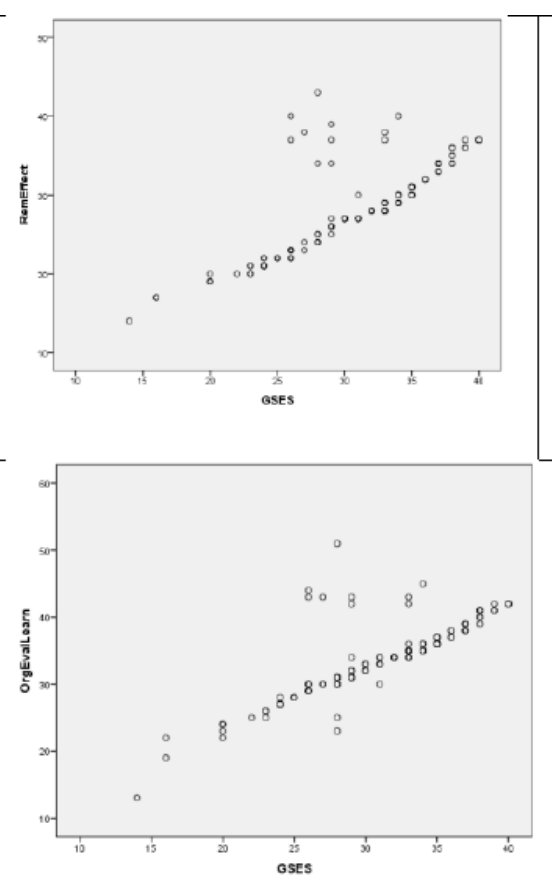

Figure 3: Scatter Plot of the Assumption of Linearity; Self-efficacy with Components of SILL
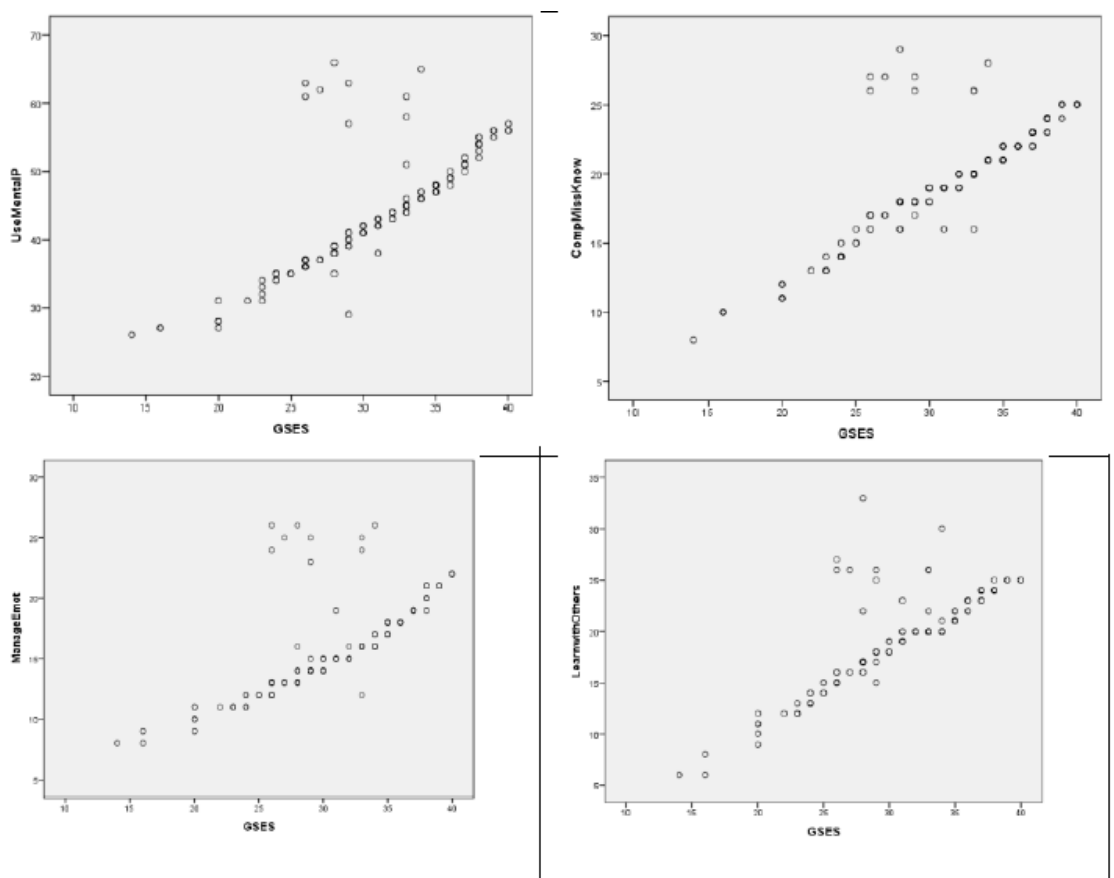

\section{The Fourth Research Question}

The results of the Pearson correlations (Table 9) run to probe significant relationships between the eight components of metacognitive awareness (MAI) and six components of language learning strategies (SILL) were all significant ( $p$ $<.05)$. The highest correlation was between Compensation Strategy and Evaluation $(\mathrm{R}=.90, p<.05)$. All the Pearson correlations enjoy large effect size $(\mathrm{R}>.50)$. 
TABLE 9:

PEARSON CORRELATION OF COMPONENTS OF GSES WITH COMPONENTS OF SILL

\begin{tabular}{|c|c|c|c|c|c|c|}
\hline \multicolumn{7}{|c|}{ MemoryCognitiveCompensationMetacognitive AffectiveSocial } \\
\hline \multirow{2}{*}{ Declarative knowledge } & R. $813^{* *}$ & $.829^{* *}$ & $.885^{* *}$ & $.843^{* *}$ & $.792^{* *}$ & $.828^{* *}$ \\
\hline & P.000 & .000 & .000 & .000 & .000 & .000 \\
\hline \multirow{2}{*}{ Procedural knowledge } & R.757 $7^{* *}$ & $.794^{* *}$ & $.835^{* *}$ & $.816^{* *}$ & $.758^{* *}$ & $.824^{* *}$ \\
\hline & $\overline{P .000}$ & .000 & .000 & .000 & .000 & .000 \\
\hline \multirow{2}{*}{ Conditional knowledge } & R.773 ${ }^{* *}$ & $.795^{* *}$ & $.828^{* *}$ & $.806^{* *}$ & $.761^{* *}$ & $.827^{* *}$ \\
\hline & P.000 & .000 & .000 & .000 & .000 & .000 \\
\hline \multirow{2}{*}{ Planning } & R. $828^{* *}$ & $.858^{* *}$ & $.899^{* *}$ & $.875^{* *}$ & $.819^{* *}$ & $.858^{* *}$ \\
\hline & P.000 & .000 & .000 & .000 & .000 & .000 \\
\hline \multirow{2}{*}{ Information Management } & $\mathrm{R} .824^{* *}$ & $.837^{* *}$ & $.861^{* *}$ & $.858^{* *}$ & $.801^{* *}$ & $.870^{* *}$ \\
\hline & $\overline{\mathrm{P} .000}$ & .000 & .000 & .000 & .000 & .000 \\
\hline \multirow{2}{*}{ Debugging Strategy } & R.778 & $.817^{* *}$ & $.868^{* *}$ & $.869^{* *}$ & $.757^{* *}$ & $.843^{* *}$ \\
\hline & $\overline{\mathrm{P} .000}$ & .000 & .000 & .000 & .000 & .000 \\
\hline \multirow{2}{*}{ Comprehension Monitoring } & R. $800^{* * *}$ & $.812^{* *}$ & $.853^{* *}$ & $.834^{* *}$ & $.772^{* *}$ & $.832^{* *}$ \\
\hline & 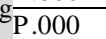 & .000 & .000 & .000 & .000 & .000 \\
\hline \multirow{2}{*}{ Evaluation } & R. $874^{* *}$ & $.869^{* *}$ & $.908^{* *}$ & $.888^{* *}$ & $.858^{* *}$ & $.887^{* *}$ \\
\hline & P.000 & .000 & .000 & .000 & .000 & .000 \\
\hline
\end{tabular}

\section{The Fifth Research Question}

A regression analysis was run to predict total SILL by using general self-efficacy and total MAI. As displayed in Table 4.7, the metacognitive awareness entered the model as the best predictor of SILL $\left(\mathrm{R}=.87, \mathrm{R}^{2}=.759\right)$. Also, MAI can predict 75.9 percent of SILL.

TABLE 10:

MODEL SUMMARY; SILL ON MAI AND GSES

\begin{tabular}{lllll}
\hline Model & R & R Square & Adjusted R Square & Std. Error of the Estimate \\
\hline $\begin{array}{l}\text { l } \\
\text { a. Predictors: (Constant), MAI }\end{array}$ & .759 & .757 & 15.868 \\
\hline b. Dependent Variable: SILL
\end{tabular}

The results of the ANOVA test of significance of the regression model $[\mathrm{F}(1,141)=444.01, p<.05]$ (Table 11$)$ indicated that the results displayed in Table 10 were statistically significant.

TABLE 11:

ANOVA TEST OF SIGNIFICANCE OF REGRESSION MODEL; SILL ON MAI AND GSES

\begin{tabular}{lllllll}
\hline Model & \multicolumn{7}{l}{ Sum of Squares } & Df & Mean Square & F & Sig. \\
\hline \multirow{2}{*}{1} & Regression & 111801.595 & 1 & 111801.595 & 444.016 & $.000^{\mathrm{b}}$ \\
\cline { 2 - 7 } & Residual & 35503.244 & 141 & 251.796 & & \\
\cline { 2 - 6 } & Total & 147304.839 & 142 & & & \\
\hline
\end{tabular}

The assumption of homoscedasticity was not met. As displayed in Figure 4 the spread of dots did not show a cloud shape. As noted by Filed (2009), when the assumption of homoscedasticity is violated, the results of the regression analysis can only be applied to the immediate population from which the sample was selected. In other words, the results would not be generalizable to other contexts.

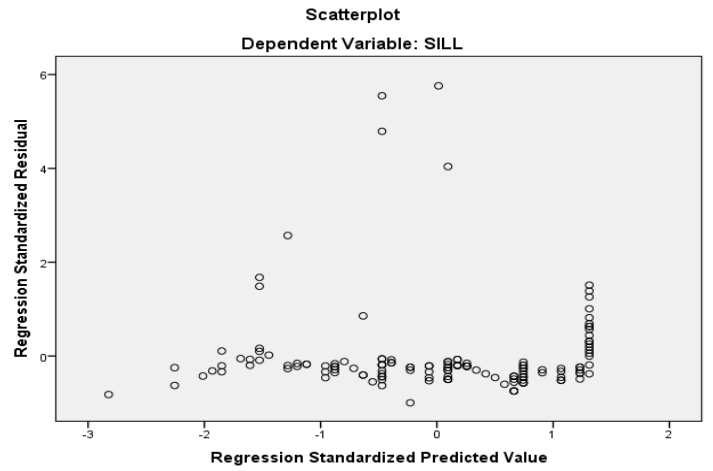

Figure 4: Testing Assumption of Homoscedasticity; SILL on MAI and GSES

The assumption of multicollinearity was also met (Table 12). The variance inflation rate (VIF) is lower than 10 and tolerance is higher than $.1(.162)$. 
TABLE 12:

MULTICOLLINEARITY STATISTICS; SILL ON MAI AND GSES

\begin{tabular}{|c|c|c|c|c|c|c|c|c|}
\hline \multirow{2}{*}{\multicolumn{2}{|c|}{ Model }} & \multirow[b]{2}{*}{ Beta In } & \multirow[b]{2}{*}{$T$} & \multirow[b]{2}{*}{ Sig. } & \multirow[b]{2}{*}{ Partial Correlation } & \multicolumn{3}{|c|}{ Collinearity Statistics } \\
\hline & & & & & & Tolerance & VIF & Minimum Tolerance \\
\hline 2 & $\overline{\text { GSES }}$ & $.036^{\mathrm{b}}$ & .353 & .725 & .030 & .162 & 6.167 & .162 \\
\hline
\end{tabular}

b. Predictors in the Model: (Constant), MAI

The results of Cook's distance indicated there were not any significant outliers (Table 13). The minimum (0) and maximum (.13) Cook's distances are lower than one.

TABLE 13:

COOK'S DISTANCE

\begin{tabular}{|l|l|l|l|l|l|}
\hline & Minimum & Maximum & Mean & Std. Deviation & N \\
\hline Cook's Distance & .000 & .134 & .005 & .019 & 143 \\
\hline a. Dependent Variable: SILL & \multicolumn{7}{|l|}{} \\
\hline
\end{tabular}

\section{DisCUSSION}

The findings of the current study show that there is a significant relationship between language learning strategies and metacognitive awareness. It can be interpreted that learners with a high degree of metacognitive awareness are more language learning strategy users. This means that strong metacognitive beliefs and the use of language learning strategies empower second language learners. Having positive beliefs in metacognitive and adjusting their language learning strategies in learning may result learners to obtain higher grades. A number of studies indicate that metacognitive awareness determines students' success in second language learning (e.g. Anderson, 1991; Chamot, Barnhardt, El-Dinnary, \& Rubbins, 1999; Oxford, 2001; Wenden, 1991). This result is also consistent with Mevarech \& Kramarski's (2003) idea that metacognition should be embedded in the learning process, and supports Rasekh \& Ranjbary's (2003) conclusion that metacognitive awareness contribute to improvements in students' vocabulary learning. An important aspect in regarding oneself as a successful learner can be self-control over the use of language learning strategies (Paris \& Winograd, 1990). This kind of self-control would improve if language learning strategy instruction is merged with metacognitive awareness (Paris \& Winograd, 1990). Learners who have greater metacognitive awareness comprehend the similarity between a new learning task and previous ones, recognize those strategies required, and predict that using these strategies will bring about success (Paris \& Winograd, 1990).

Also, based on the results of this study a significant relationship between use of language learning strategies and general self-efficacy was found. It can be interpreted that learners with a high sense of self-efficacy are more language learning strategy users. This means that students who perceived themselves as more confident in their language learning abilities are better language learning strategy users. Self-confident learners then may be more ready to take on challenging learning tasks. As Zimmerman \& Pons (1986) claim employing strategies have been linked to a sense of self-efficacy which leads to anticipation of good learning. The growth of an individual's self-efficacy or level of confidence in successfully completing a task is closely related to efficient use of language learning strategies (Zimmerman, 1990). The results of the present study is in line with the findings of researchers such as Azrien \& Adnan, 2011; Dreyer, 1992; Green \& Oxford, 1995; Magogwe \& Oliver, 2007, which show that there is an obvious link between self-efficacy and language learning strategy use. Pajares (2003) asserted that most difficulties of students originate from students' self-beliefs. In many situations students' low self-beliefs are the reason for low motivation, participation, performance and achievement rather than their lack of abilities and skills.

Besides, Heidari, Izadi, \& Vahed Ahmadian (2012) explored the relationship between Iranian EFL learners' selfefficacy beliefs and their use of vocabulary learning strategies. The obtained results revealed that students had rather high level of self-efficacy which was positively associated with their use of the four subcategories of vocabulary learning strategies in general and the use of memory strategies in particular. Those learners who are highly selfefficacious use vocabulary strategies much more than those with low self-efficacy. This result is supported by the findings of Magogwe, Mokuedi, \& Oliver (2007) who found a significant relationship between use of language learning strategies and self-efficacy beliefs.

It should be said that the above-mentioned results are opposed to the findings of Bonyadi, Rimani Nikou, \& Shahbaz (2012) who investigated the relationship between EFL learners' self-efficacy and use of language learning strategies. They found that there is no significant relationship between self-efficacy and language learning strategy use. The reason for the difference between the finding of this study and Bonyadi et al.'s study is probably due to the difference in proficiency levels of participants in these two studies. The Bonyadi et al.'s participants were a group of 130 freshmen, while the participants of this study were among sophomore, junior, and senior students.

Moreover, the study reveals that there is a significant relationship between Metacognitive awareness and general selfefficacy. In other words, students' with high sense of self-efficacy are likely to have high metacognitive awareness. This result is somehow in line with the findings of Savia (2008) who found that the relationship between metacognitive awareness and performance was deeply influenced by self-efficacy. This means that learners with reasonable 
metacognitive awareness also have strong belief in their own capabilities to successfully undertaking a task. This finding was in line with the findings obtained by Coutinho, 2007; Kruger \& Dunning, 1999; Multon, Brown, \& Lent, 1991. Their studies in self-efficacy and metacognitive awareness have already shown that both self-efficacy and metacognitive awareness are essential to successful learning. Students should be persuaded to analyze and inspect their own learning processes to improve their degree of metacognitive awareness, which may reinforce their sense of selfefficacy. Sinclair (2000) suggested that when there is not an explicit awareness of the processes involved in learning, learners will not be able to make informed decisions about their own learning.

It is recommended that the teachers, by considering the findings of this study, not contribute the failure of the students completely to their weak knowledge or inadequate skills but to different individual characteristics of the learners in the process of learning such as self-efficacy, metacognitive awareness, and language learning strategy use. They are expected to teach and encourage the learners how to use these strategies and take the maximum benefit of them in the process of their learning.

When learners believe in their abilities to perform tasks, they would create deeper interest in learning and developing their confidence in order to overcome difficulties of learning. Highly self-efficacious learners also exhibit higher engagement in the classroom and better academic performance. Accordingly, instructors should improve the sense of self-efficacy in their students which would be beneficial to their achievement. Cotterall (1999) has stated that it is crucial to provide teachers with a means of identifying and supporting individual learners who need to develop their sense of self-efficacy. If this can be done before they engage in learning tasks, the ensuing intervention in their language learning experience should result in superior performance.

Based on the results of this study, a positive significant correlation was found between EFL learners' self-efficacy and their metacognitive awareness, which means that promoting metacognitive awareness may enhance student selfefficacy. In the process of learning, if teachers design tasks to help the students increase their self-efficacy and metacognitive awareness, this increase might have positive effect on their academic performance. Since, it is very important for students to understand the importance of using language learning strategies in the process of language learning; hence, EFL teachers should deliver this message to their students. Teachers should help students cultivate and raise their awareness of language learning strategies. Once students are aware of advantages of using strategies in their language learning process, they will be willing to appropriately employ these strategies to facilitate their learning.

Due to the fact that language learning is a multidimensional phenomenon, not only language teachers, but also language learners themselves are required to play their role properly in order to facilitate and optimize this complicated process. Therefore, the results of the current study have implications for language learners, encouraging them to become more conscious and autonomous. The findings provide information for language learners by indicating that self-beliefs of language ability can affect their language achievement depending on the strength of their efficacy beliefs. Pajares (2000) states that many, if not most, academic crises are confidence crises.

Syllabus designers as providers of a great portion of the language learning setting, have a fundamental role to make the learning process easier. They are required to know that incorporation of language learning strategies in their courses can result in intellectual analytical learners that through using strategies can overcome their learning difficulties. When relevant training hints or motivation are inserted in appropriate parts of a course book with different tasks, teachers are provided with a powerful device to optimize language learning activities, which may result in promoting the learners' metacognitive awareness and self-efficacy.

\section{REFERENCES}

[1] Abedini, A., Rahimi, A., \& Zaree, A. (2011). Relationship between Iranian EFL learners' beliefs about language learning, their language learning strategy use and their language proficiency. Procedia-Social and Behavioral Sciences, 28,1029 - 1033.

[2] Anderson, N. J. (1991). Individual differences in strategy use in second language reading. Modern Language Journal, 75, 460472.

[3] Azrien. M, \& Adnan.M. (2011). Language learning strategies and self-efficacy belief in Arabic language earning: A Malaysian context. AJTLH, 3, 50-59.

[4] Bandura. (1986). Social foundations of thought and action: A social cognitive theory. Englewood Cliffs: Prentice Hall.

[5] Bandura, A. (1989). Social cognitive theory. In R. Vasta (Ed.), Annals of child development. Vol. 6. Six theories of child development (pp. 1-60). Greenwich, CT: JAI Press.

[6] Bastani, F. (2012). The effect of education on nutrition behavioral intention and self. Health Scope, 1 (1), 12-17.

[7] Bonyadi, A., Rimani Nikou, F., \& Shahbaz, S. (2011). The relationship between EFL learners' self-efficacy beliefs and their language learning strategy use. English Language Teaching, 5 (8), 113-121.

[8] Bouffard-Bouchard, T., Parent, S., \& Larivèe, S. (1991). Influence of self-efficacy on self-regulation and performance among junior and senior high-school aged students. International Journal of Behavioral Development, 14, 153-164.

[9] Brown, H. D. (2000). Principles of language learning and teaching (4th ed.). New York: Longman.

[10] Brown, H. D. (2007). Principles of language learning \& teaching (5th ed.). New York: Longman.

[11] Carson, J. G., \& Longhini, A. (2002). Focusing on learning styles and strategies: A study in an immersion setting. Language Learning, 52, 401-438.

[12] Chamot, A. (2001). The role of learning strategies in second language acquisition. In Learner contributions to language learning: New directions in research (pp. 25-43). Harlow, England: Longman. 
[13] Chamot, A. (2004). Issues in language learning strategy research and teaching. Electronic Journal of Foreign Language Teaching, 1, 14-26.

[14] Chamot, A.U., Barnhardt, S., El-Dinnary, P.B. \& Rubbins, J. (1999). The learning strategies handbook. York: Longman.

[15] Chou, C. (2007). A study on the relationships among English self-efficacy, English learning anxiety, English learning strategies and English learning achievement of senior high school students. Unpublished doctoral dissertation, National Taiwan Normal University, Taipei, Taiwan.

[16] Conner, L. N. (2006). Cuing metacognition to improve researching and essay writing. Research in Science Education, 37 (1), $72-78$.

[17] Cotterall, L. (1999). Key variables in language learning: What do learners believe about them? System, 27, 493-513.

[18] Coutinho, S. (2007). The relationship between goals, metacognition, and academic success. Educate, 7 (1), 39-47.

[19] Çubukçu, F. (2008). A study on the correlation between self-efficacy and foreign language learning anxiety. Journal of Theory and Practice in Education, 4 (1), 148-158.

[20] Dehdari, T., Heidarnia, A., Ramezankhani, A., Sadeghian, S., \& Ghofranipour, F. (2008). Anxiety, self-efficacy expectation and social support in patients after coronary angioplasty and coronary bypass. Iranian Journal Publication Health, 37 (4), 119 125.

[21] Delavarpoor, \& Motahedi. (2007). Predicted metacognitive awareness and academic progress based on achievement goal. Journal of Psychology, Tabriz University, 9, 65-91.

[22] Dörnyei, Z. (2009). Individual differences: Interplay of learner characteristics. Language Learning, 59 (1), 230-248.

[23] Dreyer, C., \& Oxford, R. (1996). Learner variables related to ESL proficiency among African speakers in South Africa. Honolulu: University of Hawaii at Manoa.

[24] Ehrman, M., \& Oxford, R. (1995). Cognition plus: Correlates of language learning success. Modern Language Journal, 79 (1), $67-89$.

[25] Elias, H., Mahyuddin, R., Noordin, N., Abdullah, M. C., \& Roslan, S. (2009). Self-efficacy beliefs of at-risk students in Malaysian secondary schools. The International Journal of Learning, 16, 201-210.

[26] Fewell, N. (2010). Language learning strategies and English language proficiency: An investigation of Japanese EFL university students. TESOL Journal, 2, 159-174.

[27] Field, A. (2009). Discovering statistics using SPSS. (3rd ed.). London: Sage.

[28] Green, J. M., \& Oxford, R. L. (1995). A closer look at learning strategies, L2 proficiency, and gender. TESOL Quarterly, 29 (2), 261-297.

[29] Grenfell, M., \& Harris, V. (1999). Modern languages and learning strategies: In theory and practice. London: Routledge.

[30] Griffiths, C., \& Parr, J. (2000). Language-learning strategies: Theory and perception. ELT Journal, 53 (3), $247-254$.

[31] Heidari, F. \& Bahrami, Z. (2012). The relationship between thinking styles and metacognitive awareness among Iranian EFL learners. International Journal of Linguistics, 4 (3), 721-733.

[32] Heidari, F., Izadi, M., \& Vahed Ahmadian, M. (2012). The relationship between Iranian EFL learners' self-efficacy beliefs and use of vocabulary learning strategies. English Language Teaching, 5 (2), 174-182.

[33] Ho, L. (2005). The relationships among self-efficacy, collective efficacy, and academic performance of middle school students. Unpublished master's thesis, National Changhua University of Education, Changhua, Taiwan.

[34] Hsiao, T., \& Oxford, R. (2002). Comparing theories of language learning strategies: A confirmatory factor analysis. The Modern Language Journal, 86(3), 368- 383.

[35] Jalaluddin. I. (2013). Predicting writing performance outcome via writing. World Applied Sciences Journal, 26(5), 643-652.

[36] Kruger, J., \& Dunning, D. (1999). Unskilled and unaware of it: How differences in recognizing one's own incompetence lead to inflated self-assessments. Journal of Personality and Social Psychology, 77(6), 1121-1134.

[37] Lin, Q. Y. (2002). The study of the effects of English learning motivation regulating training group in self-efficacy, learning motivation and the academic performance for senior high school students. Unpublished master's thesis, National Changhua University of Education, Changhua, Taiwan.

[38] Livingstone, J. A. (2003). Metacognition: An overview. New York: National Center for Research on Teacher Learning.

[39] Magogwe, Mokuedi, J., \& Oliver, R. (2007). The relationship between language learning strategies, proficiency, age and selfefficacy beliefs: A study of language learners in Botswa. System, 35, 338-352.

[40] Marzoogh, R., \& Safari, Y. (2009). Evaluation of experimental science of guidance school from the perspective of metacognitive training. Curriculum Studies Publication, 3 (10), 20-38.

[41] Mevarech, Z. R. \& Kramarski, B. (2003). Improve: A multidimensional method for teaching. American Educational Research Journal, 34 (2), 365-394.

[42] Mills, N., Pajares, F., \& Herron, C. (2007). Self-efficacy of college intermediate French students: Language Learning, 57 (3), 417-442.

[43] Multon, K. D., Brown, S. D., \& Lent, R. W. (1991). Relation of self-efficacy beliefs to academic outcomes: A meta-analytic investigation. Journal of Counseling Psychology, 38, 30-38.

[44] Nunan, D. (1988). The learner-centered curriculum. Cambridge: University Press.

[45] Oxford, R. L. (1990). Language learning strategies: What every teacher should know. Boston: Heinle \& Heinle.

[46] Oxford, R.L. (2001). Language learning styles and strategies. In M. Celce-Murcia (Ed.), Teaching English as a second language (pp. 359-366). Boston: Heinle \& Heinle.

[47] Oxford, R. L. (2003). Language learning styles and strategies: An overview, GALA, pp. 1-25. Retrieved November 9, 2012, from web.ntpu.edu.tw/ language/workshop/read2.pdf.

[48] Oxford, R. \& Anderson, N. (1995). A cross cultural view of learning style. Language Teaching, 28(4), 201-215.

[49] Pajares, F. (2000). Self-efficacy beliefs and current directions in self-efficacy research. Retrieved June 6, 2013 from http://www.emory.edu/EDUCATION/mfp/effpage.html.

[50] Pajares, F. (2003). Self-efficacy beliefs, motivation, and achievement: A review of the literature. Reading\& Writing Quarterly, 19 (2), 139-158. 
[51] Paris, S. G., \& Winograd, P. (1990). Promoting metacognition and motivation of exceptional children. Remedial and Special Education, 11 (6), 7-15.

[52] Rasekh, Z. E., \& Ranjbary, R. (2003). Metacognitive strategy training for vocabulary learning. Teaching English as a Second or Foreign Language, 7(2), 1-15.

[53] Riazi, A. (2007). Language learning strategy use: Perceptions of female Arab English majors. Foreign Language Annals, 40 (3), 433-440.

[54] Riazi, A., \& Rahimi, M. (2005). Iranian EFL learners' pattern of language learning strategy use. The Journal of Asia TEFL, 2 , $103-129$.

[55] Schraw, G., \& Dennison, R. (1994). Assessing metacognitive awareness. Contemporary Educational Psychology, 19, $460-475$.

[56] Schwarzer, R., \& Born, A. (1997). Optimistic self-beliefs: Assessment of general perceived self-efficacy in thirteen cultures. World Psychology, 3(1-2), 177-190.

[57] Schwarzer, R., \& Jerusalem, M. (1995). Generalized self-efficacy scale. In S. \&. J. Weinman, Measuresin health psychology: A user's portfolio causal and control beliefs (pp. 35-37). Windsor, UK: NFER-NELSON.

[58] Schwarzer, R., Bäßler, J., Kwiatek, P., Schröder, K., \& Zhang, J. X. (1997). In Schwarzer, R., Bäßler, J., Kwiatek, P. The assessment of optimistic self-beliefs: Comparison of the German, Spanish, and Chinese versions of the General Self-Efficacy Scale. Applied Psychology: An International Review, 46 (1), 69-88.

[59] Schwarzer, R., Born, A., Iwawaki, S., Lee, Y.-M., Saito, E., \& Yue, X. (1997). The assessment of optimistic self-beliefs: Comparison of the Chinese, Indonesian, Japanese and Korean versions of the general self-efficacy scale. Psychologia: An International Journal of Psychology in the Orient, 40 (1), 1-13.

[60] Shahniyeilagh, M., Boostani, F., Alipoor, S., \& Hajiyakhchali, A. (2012). Self-efficacy, metacognition and achievement goals. Journal of psychology and educational studies, 16, 81-110.

[61] Siew, L., \& Wong, M. (2005). Language learning strategies and language self. Eric Journal, 36 (3), 245-269.

[62] Sinclair, B. (2000). Learner autonomy: The next phase. In Sinclair, B, McGrath, I \& Lamb, T. (eds) Learner autonomy, teacher autonomy: Future directions. London: Pearson Education.

[63] Sperling, R. A., B. C., H., Staley, R., \& DuBois, N. (2004). Metacognition and self-regulated learning constructs. Educational Research and Evaluation, 10 (2), 117-139.

[64] Tahmasebi, A. (1999). Vocabulary learning strategy and the level of language proficiency. Unpublished Master of Arts thesis. Tehran, Iran: Tarbiat Modares University.

[65] Wenden, A. (1991). What do second-language learners know about their language learning? Applied Linguistics, 7, 186-205.

[66] Wharton, G. (2000). Language learning strategy use of bilingual foreign language learners in Singapore. Language Learning, 50 (2), 203-244.

[67] White, B. Y., \& Frederiksen, J. R. (1998). Inquiry, modeling, and metacognition: Making science accessible to all students. Cognition and Instruction, 16, 3-118.

[68] Winne, P. (1995). A metacognitive view of individual differences in self-regulated learning. Learning and Individual Differences, 8, 327-353.

[69] Winne, P. H., \& Hadwin, A. F. (1998). Studying as self-regulated learning. Metacognition in educational theory and practice, 93, 27-30

[70] Zare, P., \& Noordin, N. (2011). The relationship between language learning strategy use and reading comprehension achievement among Iranian undergraduate EFL learners. World Applied Sciences Journal, 13(8), 1870-1877.

[71] Zare, P. (2010). An investigation into language learning strategy use and gender among Iranian undergraduate language learners. World Applied Sciences Journal, 11 (10), 1238-1247.

[72] Zhang, L. F. (2010). Further investigating thinking styles and psychosocial development in the Chinese higher education context. Learning and Individual Differences, 20 (6), 593-603.

[73] Zimmerman, B. J. (1990). Self-regulated learning and academic achievement: An overview. Educational Psychologist, 25 (1), 3-17.

Mania Nosratinia is Assistant Professor of Applied Linguistics at Islamic Azad University, Central Tehran Branch. She has been teaching at undergraduate and graduate levels in the areas of English language teaching methodology, language testing, and re search methodology in language studies. She has published in national and international academic journals and presented in several national and international seminars.

Maryam Saveiy holds an MA in TEFL from Islamic Azad University at Central Tehran and is an English teacher at a number of language schools. Her main areas of research interest include psycholinguistics and language learning strategies.

Alireza Zaker is currently a Ph.D. student of TEFL, Islamic Azad University, Science and Research Campus, Tehran. His specific areas of ELT research include Language Testing, Research Methodology, Teacher Education, and Critical Thinking. He has published in international academic journals and presented in several national and international ELT conferences. 